Volume 10, No.1, January - February 2021

International Journal of Advanced Trends in Computer Science and Engineering

Available Online at http://www.warse.org/IJATCSE/static/pdf/file/ijatcse571012021.pdf

https://doi.org/10.30534/ijatcse/2021/571012021

\title{
Experimental Strength Evaluation of Bamboo Reinforced Concrete Beams
}

\author{
Muhammad Fahim*1, Muhammad Ashfaq ${ }^{2}$, Obaid Safdar², Muhammad Waseem Khan², Saeed Zaman ${ }^{2}$, Shahid Ullah ${ }^{1}$ \\ ${ }^{1}$ Lecturer, Civil Engineering Department, University of Engineering and Technology, Peshawar, Pakistan. \\ ${ }^{2}$ Student, Civil Engineering Department, University of Engineering and Technology, Peshawar, Pakistan.
}

\section{ABSTRACT}

This paper presents the outcome of an experimental investigation of the behavior and strength of reinforced concrete beams with bamboo reinforcement. A total of five beam specimens were tested in flexural under four point (pure bending) loading. A plain concrete beam (B1) served as a control beam. Two specimens (B2 and B3) were longitudinally reinforced with four bamboo culms and steel stirrups. The last two specimens (B4 and B5) had similar longitudinal reinforcement but bamboo pieces were used as shear stirrups. The bamboo culms used in two specimens (B2 \& B4) were treated with bitumen along with sprinkling of fine particles of sand to achieve rough surface for better bonding with concrete. The introduction of bamboo reinforcement increased the stiffness, strength, and ductility of beams significantly as compared to the plain concrete beam. The ultimate load carrying capacity of bamboo reinforced concrete beams was found to be 2.49 to 3.29 times that of control beam. The observed ultimate load was $25 \%$ and $13 \%$ more for specimens with coated reinforcement in case of steel stirrups and bamboo stirrups respectively. The specimen with coated bamboo reinforcement and steel stirrups achieved the highest ultimate load among all specimens.

Keywords:Bamboo, mechanical properties, bamboo reinforced concrete, four point loading.

\section{INTRODUCTION}

Bamboois a financially feasible, structurally strong and durable, and environmentally sustainable material [1]. It has over 1300 species and found all over the world [2]. The tensile strength of different bamboo species varies between 70-210 $\mathrm{MPa}$, compressive strength between 20-65 MPa, elastic modulus between 2500-17500 $\mathrm{MPa}$, and modulus of rupture between 50-200 MPa [3-11]. The tensile strength to specific weight ratio of some bamboo species is six times greater than that of steel [12]. Ghavami [13] found out that the mean specific weight of bamboo varies between $6.5 \mathrm{kN} / \mathrm{m} 3$ and 9 $\mathrm{kN} / / \mathrm{m} 3$. He determined the tensile strength for two species as $135 \mathrm{MPa}$ and $170 \mathrm{MPa}$, compression strength in the range 12$53 \mathrm{MPa}$, and shear strength was between $40 \mathrm{MPa}$ and $62 \mathrm{MPa}$. These characteristics make bamboo as a viable candidate for reinforcement in concrete members.

Bamboo can also be converted into an engineered material in the form of laminated sheets or bamboo scrimber. Bamboo is pressed and flattened to form laminated strips which are then glued together in layers to form laminated bamboo boards [1416]. These boards are used in similar applications as wooden plywood. The bamboo fibers are treated with adhesives and highly compressed at higher temperature to form a very compacted material known as bamboo scrimber[16]. Laminated bamboo and bamboo scrimber have shown superior behavior than existing timber [17].

Bamboo is also used as a reinforcement in concrete members. Investigation of bamboo reinforced concrete (BRC) have been reported as early as 1950 [18]. Kankam et al. tested ten simply 382 
Muhammad Fahim et al.,International Journal of Advanced Trends in Computer Science and Engineering, 10(1), January - February 2021,382 - 388 supported one-way bamboo-reinforced slabs under line loading and observed three types of failures; compression failure in concrete, both shear and compression failure in concrete, and tension failure in bamboo [19]. The authors also tested ten bamboo-reinforced concrete beams under short term monotonic loading and six beams under long term loading and observed that failure occurred through diagonal tension failure of the concrete in the shear span [20]. The behavior of BRC beams is generally far better than PCC beams. The shear and flexure behavior of $\mathrm{BRC}$ with $3.8 \%$ bamboo reinforcement becomes very similar to RCC beam with $1.23 \%$ steel reinforcement [21]. Bamboo can also be used as reinforcement in columns and slabs [22, 23].

This paper investigates the suitability of locally (Peshawar, Pakistan) available bamboo as a longitudinal and transverse reinforcement for concrete beams. These members can be used in low cost houses to improve their seismic capacity. Brick and stone masonry buildings have shown significant improvement in seismic capacity with the introduction of reinforced concrete confining elements $[24,25]$. However, due to financial constraints, many people do not incorporate these elements in their buildings. Bamboo reinforced concrete elements can be an economical and sustainable alternative to steel reinforced concrete for such buildings.

\section{MATERIAL PROPERTIES}

Two sizes of locally available bamboo were used in this study; 0.7 in. diameter culm for longitudinal reinforcement and $0.3 \mathrm{in}$. diameter culm for transverse reinforcement. The specimens are tested for tensile strength parallel to grains and tensile strength perpendicular to grains according to ASTM D638-14 and ASTM D143-14 respectively. The smooth surface of bamboo culm is not suitable for holding in the jaws of universal testing machine (UTM) during tension test. Therefore, the ends of the specimens were wrapped with GI (galvanized iron) wire along with the application of epoxy in order to make them rough and hard enough to be mounted properly in the UTM as shown in Figure 1. 

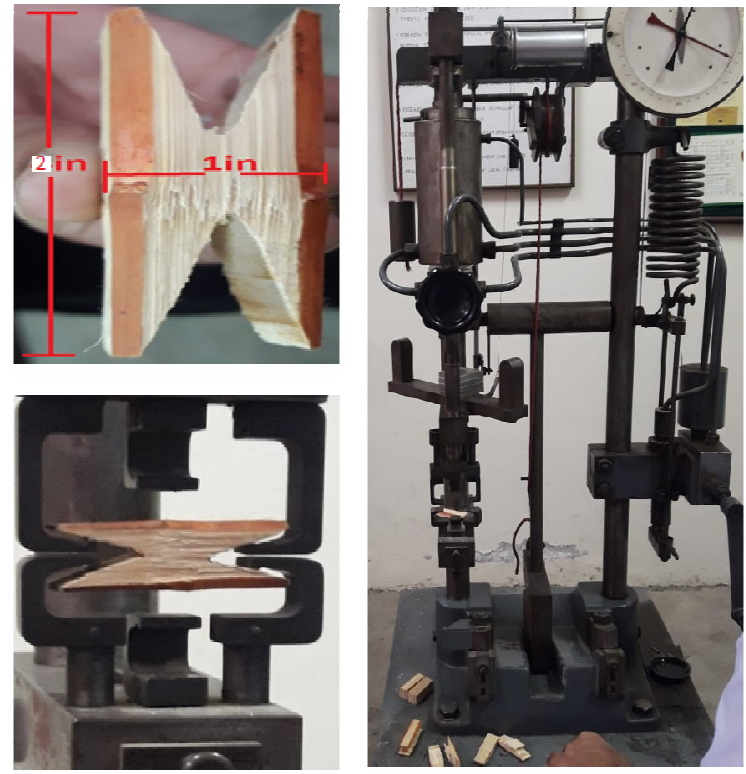

Figure 2. Test setup for tensile test perpendicular to grains

The load carried by the three samples tested was $326 \mathrm{lbs}, 333$ lbs, and $319 \mathrm{lbs}$. The mean load taken by the specimens perpendicular to grains was found to be $326 \mathrm{lbs}$. The beam specimens were casted in 1:2:4 (cement: fine aggregate: coarse aggregate) concrete commonly practiced in Pakistan with a water cement ratio of 0.5 . The average compressive strength of concrete was found to be 1570 psi. ASTM A615 Grade 40 steel with a specified yield strength of $40 \mathrm{ksi}$ was used as stirrups in two beam specimens.

\section{TEST SPECIMENS}

A total number of five beam specimens were tested; a control beam in plain concrete and four beams with bamboo as reinforcement. The longitudinal and transverse reinforcement details are given in Error! Reference source not found. and a typical long section and cross sections are shown in Figure 3. All specimens were 60 in. long and had 8 in. x 6 in. cross section. Four bamboo culms of 0.7 in. diameter were used as longitudinal reinforcement, two for compression and two for tension. Two specimens were provided with $1 / 4$ in. diameter steel stirrups at 6 in. center to center. In the remaining two specimens, 0.5 in. culms pieces at 6 in. center to center were used as stirrups.
Table 2. Reinforcement details all specimens

\begin{tabular}{|c|c|c|c|}
\hline $\begin{array}{c}\text { Speci } \\
\text { men }\end{array}$ & Description & $\begin{array}{c}\text { Longitudinal } \\
\text { rebars }\end{array}$ & $\begin{array}{c}\text { Transverse } \\
\text { reinforcement }\end{array}$ \\
\hline B1 & $\begin{array}{l}\text { Plain concrete } \\
\text { beam }\end{array}$ & NA & NA \\
\hline B2 & $\begin{array}{l}\text { Uncoated culms } \\
\text { with steel ties }\end{array}$ & \multirow{4}{*}{$\begin{array}{l}4 \text { culms of } 0.7 \\
\text { in. diameter }\end{array}$} & \multirow{2}{*}{$\begin{array}{l}1 / 4 \text { in. diameter } \\
\text { rebars @6 in. c/c }\end{array}$} \\
\hline B3 & $\begin{array}{l}\text { Coated culms } \\
\text { with steel ties }\end{array}$ & & \\
\hline B4 & $\begin{array}{l}\text { Uncoated culms } \\
\text { with bamboo ties }\end{array}$ & & \multirow{2}{*}{$\begin{array}{l}0.3 \text { in. diameter } \\
\text { culm @6 in. c/c }\end{array}$} \\
\hline B5 & $\begin{array}{l}\text { Coated culmswith } \\
\text { bamboo ties }\end{array}$ & & \\
\hline
\end{tabular}

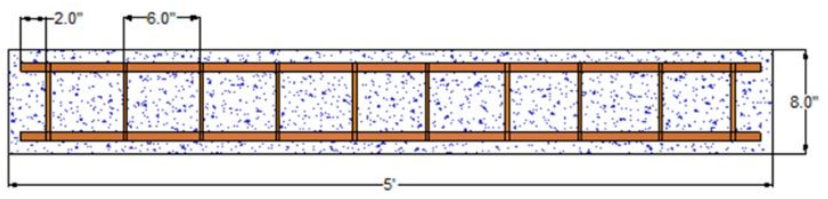

(a)
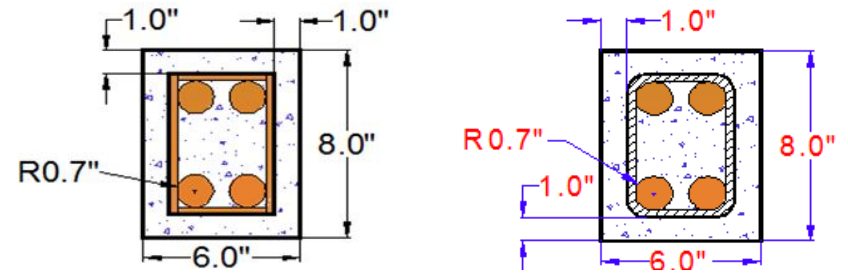

(b)

Figure 3. (a) Long section of the test specimen, (b) Cross sections of the test specimens

In order to strengthen the bond between concrete and bamboo and to reduce water absorption of bamboo, reinforcement skeletons in two specimens (one with steel stirrups and one with bamboo stirrups) are coated with coal tar along with sprinkling of sand.A typical coated reinforcement cage is shown in Error! Reference source not found..

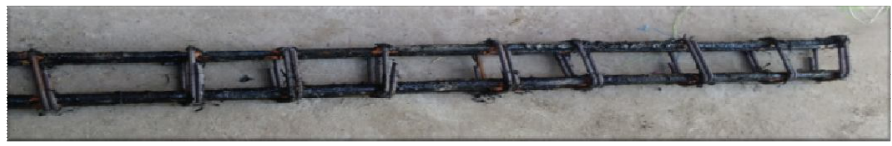

Figure 4. Coated reinforcement cage with steel stirrups

The last two specimens had uncoated reinforcement with aim to get behavior of specimens with both coated and uncoated reinforcement. A typical uncoated reinforcement cage with bamboo stirrups is shown inError! Reference source not found. 


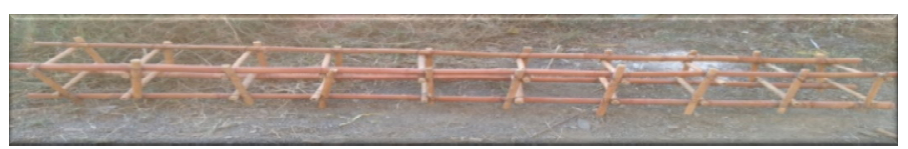

Figure 5. Uncoated reinforcement cage with bamboo stirrups

The specimens were tested under four point loading (pure bending) as shown in Error! Reference source not found..

The load was gradually increased until failure of the specimens.

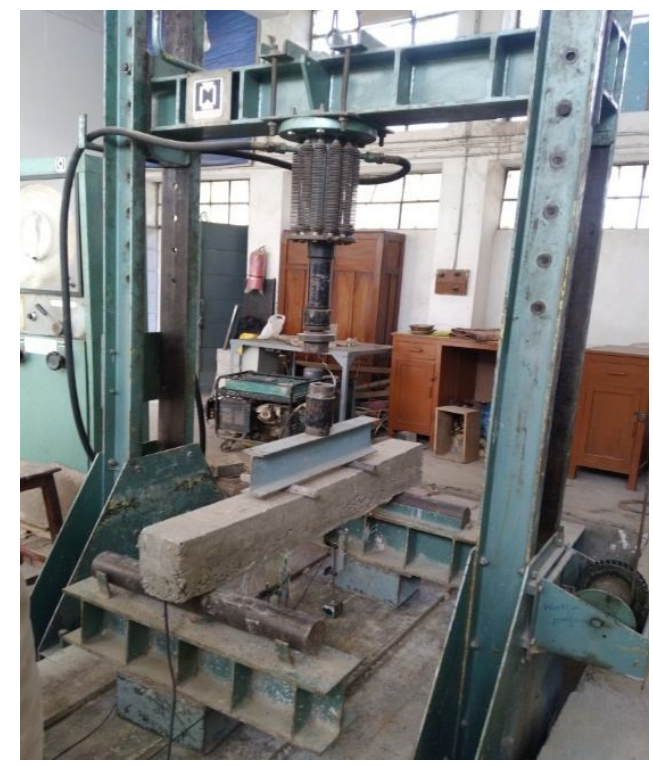

Figure 6. Test setup for four point loading

\section{RESULTS AND DISCUSSION}

The test results for specimens B2 and B3 are represented as load vs midspan deflection in Figure 7 and 8 . The results for control beam are also shown in each figure for comparison. The introduction of bamboo reinforcement increased the stiffness, strength, and ductility of beams significantly as compared to the plain concrete beam. The ultimate load for B2 (uncoated culms with steel stirrups) and B3 (coated culms with steel stirrups) was recorded as 8.69 kips and 10.90 kips respectively. The coating resulted in $25 \%$ increase in ultimate load carrying capacity of specimen B3 as compared to B2. Moreover, the ultimate displacement was also significant higher in B3 as compared to B2.

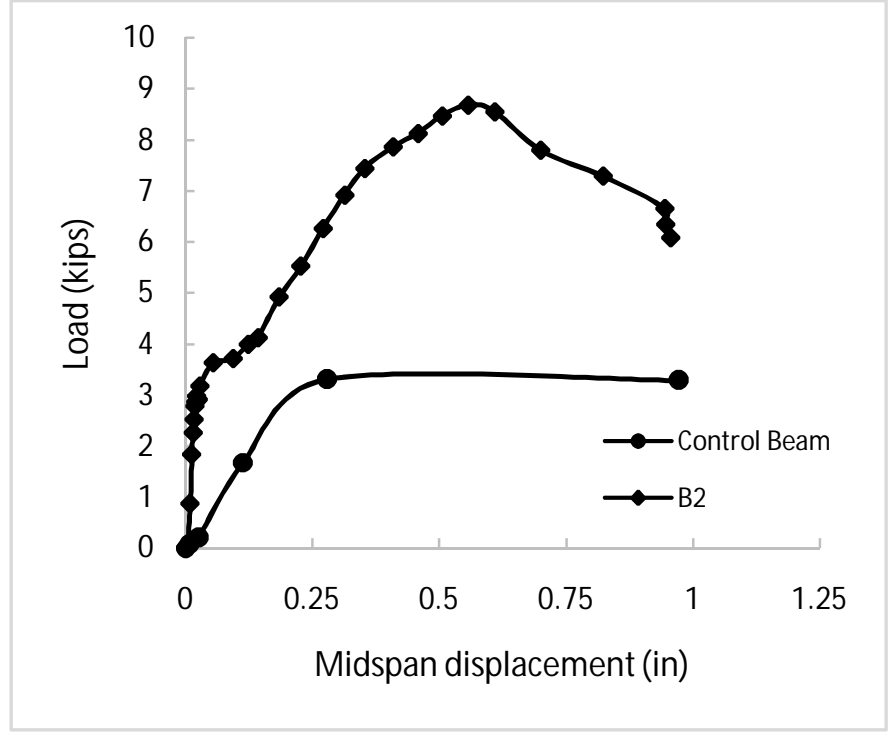

Figure 7. Load-deflection relations of specimen B2 and control beam

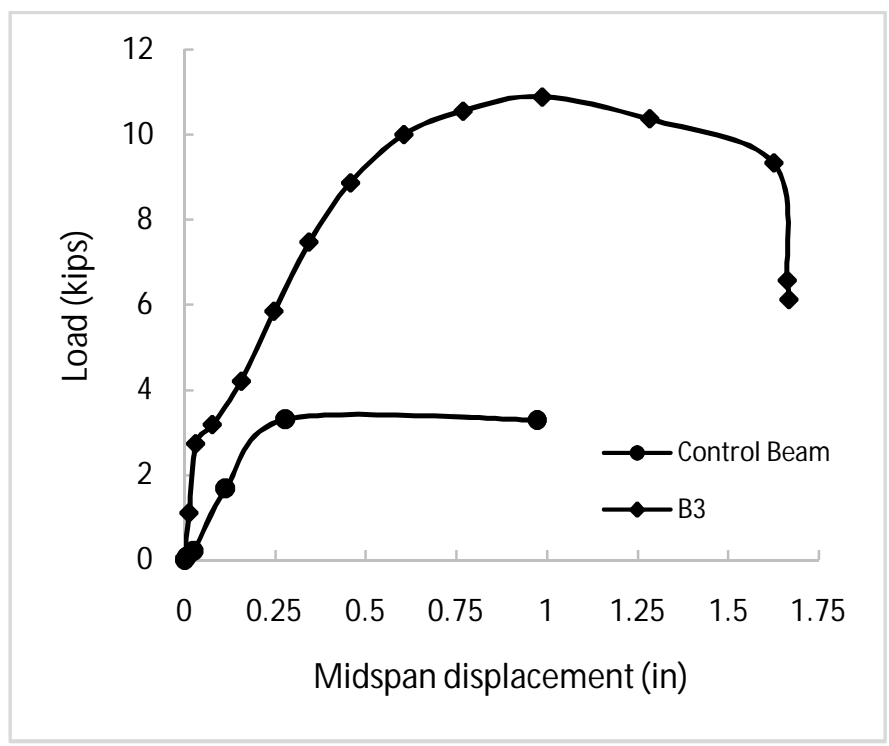

Figure 8. Load-deflection relations of specimen B3 and control beam

The final cracking of specimens B2 and B3 is shown in Figure 9. A major flexure crack was observed near midspan in specimen B2 and under the point load in specimen B3. The bamboo culms appear to have hold the beams from breaking apart.

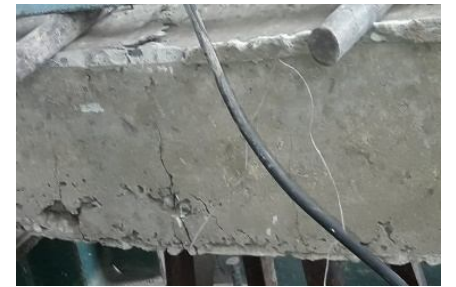

(a)

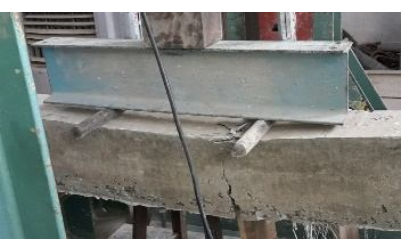

(b) 
Figure 9. a) Final cracking in specimen B2, b) Final cracking in specimen B3

The test results for specimens B4 and B5 are shown in Error!

Reference source not found.10 and 11 along with control beam. The introduction of bamboo reinforcement increased the stiffness, strength, and ductility of beams significantly as compared to the plain concrete beam. The ultimate load for B4 (uncoated culms with bamboo stirrups) and B5 (coated culms with bamboo stirrups) was recorded as 8.24 kips and 9.34 kips respectively. The coating resulted in $13 \%$ increase in ultimate load carrying capacity of specimen B5 as compared to B4.

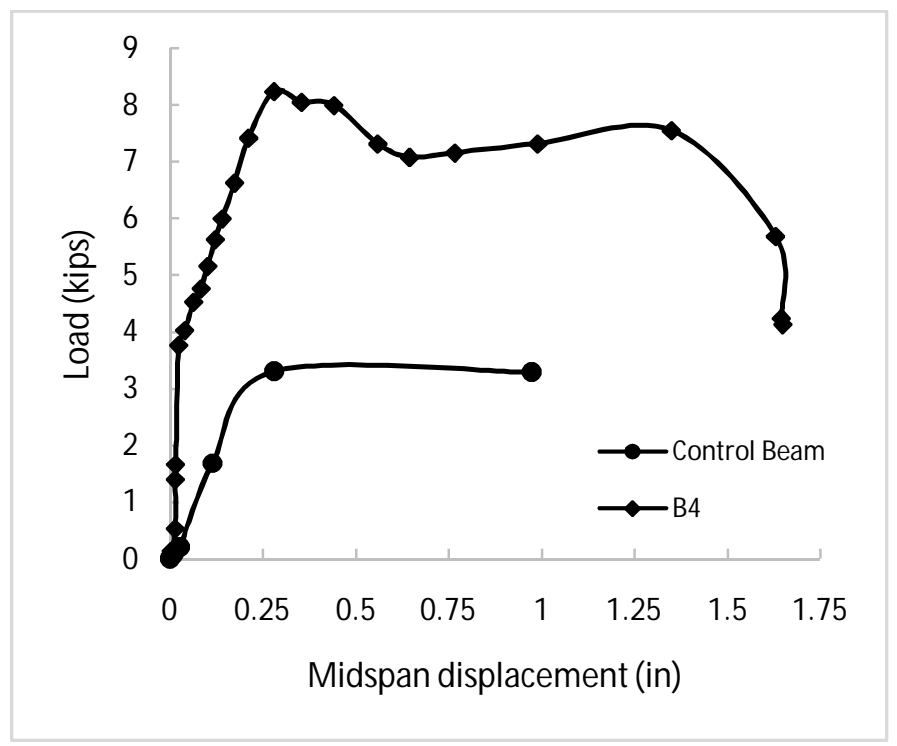

Figure 10. Load-deflection relations of specimen B4 and control beam

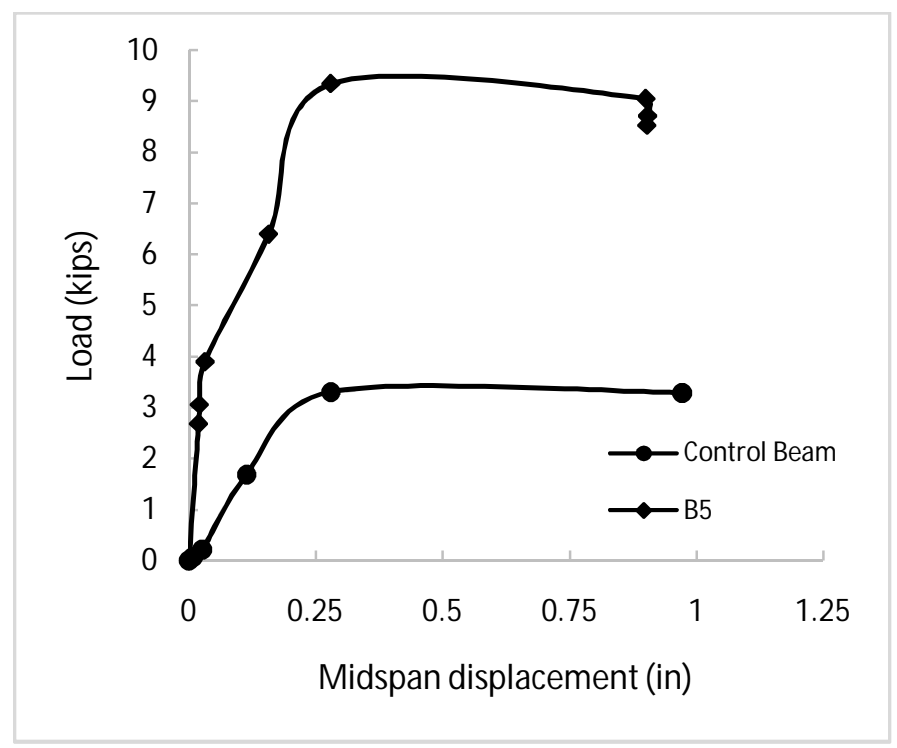

Figure 11. Load-deflection relations of specimen B5 and control beam
The final cracking of specimens B4 and B5 is shown in Figure 1212. Major flexure cracks were observed near midspan and under the point load in specimen B4 along with spalling of cover concrete. However, only one major crack was observed in specimen B5 under the point load along with spalling of concrete at the same location. The bamboo culms appear to have hold the beams from breaking apart.

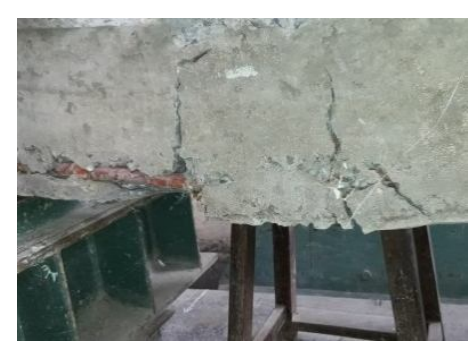

(a)

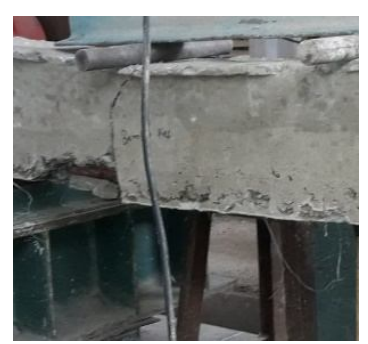

(b)
Figure 12. a) Final cracking in specimen B4, b) Final cracking in specimen B5

The combined load-deflection relationships are shown in Figure 1313 and the ultimate load and deflection values are summarized in Error! Reference source not found.. Bamboo reinforcement increased the ultimate load carrying capacity, stiffness, and ductility of all specimens significantly. The best results were obtained for specimen B3 where coated bamboo culms were used with steel stirrups. The ultimate load for specimen B3 was found to be 3.29 times the ultimate load of control beam.

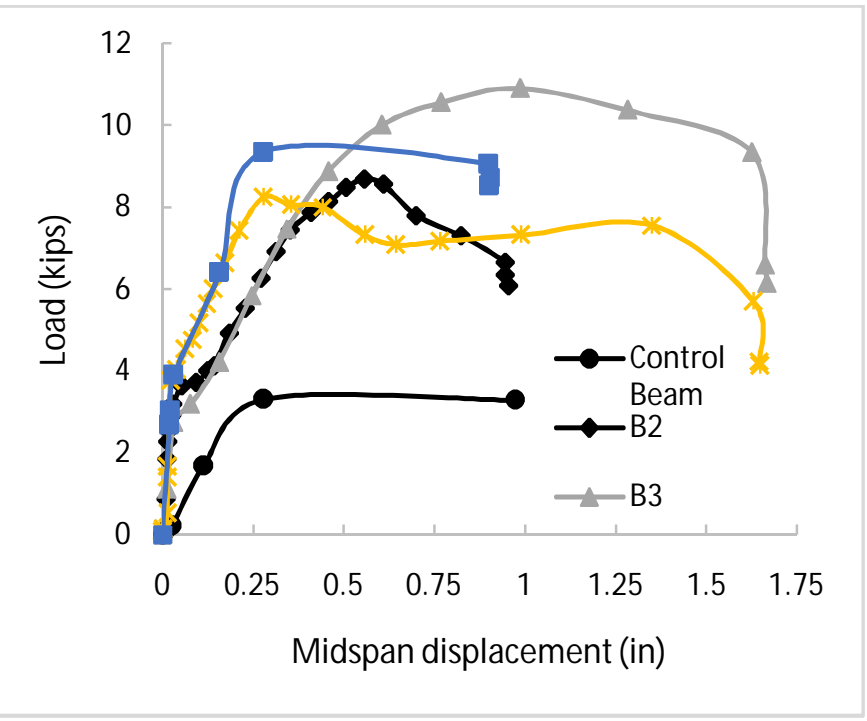

Figure 13. Load-deflection relations of all specimens 
Table 3. Ultimate load-deflection values of all specimens

\begin{tabular}{|c|c|c|c|}
\hline Specimen & $\begin{array}{c}\text { Ultimate load, } P_{u} \\
\text { (kips) }\end{array}$ & $\begin{array}{c}\text { Deflection at ultimate } \\
\text { load, } \Delta_{u}(\mathbf{i n})\end{array}$ & $\frac{P_{u}}{\left(P_{u}\right)_{B 1}}$ \\
\hline B1 & 3.31 & 0.279 & NA \\
\hline B2 & 8.68 & 0.557 & 2.62 \\
\hline B3 & 10.90 & 0.986 & 3.29 \\
\hline B4 & 8.24 & 0.280 & 2.49 \\
\hline B5 & 9.34 & 0.280 & 2.82 \\
\hline
\end{tabular}

\section{CONCLUSIONS}

The performance of bamboo reinforced concrete beams was experimentally investigated. Four concrete beams reinforced with longitudinal bamboo culms and steel/bamboo stirrups were tested under four point loading. The following conclusions can be made based on the analysis of test results:

- The tensile strength of locally available bamboo was found to be in the range $15 \mathrm{ksi}$ to $20 \mathrm{ksi}$. This makes bamboo as a potential replacement for steel reinforcement in concrete members, especially for low cost housing in rural areas.

- The introduction of bamboo reinforcement increased the stiffness, strength, and ductility of beams significantly as compared to the plain concrete beam. The ultimate load carrying capacity of bamboo reinforced concrete beams was found to be 2.49 to 3.29 times that of plain concrete beam.

- The specimens with coated reinforcement performed better than their uncoated counterparts. The observed ultimate load was $25 \%$ and $13 \%$ more for specimens with coated reinforcement in case of steel stirrups and bamboo stirrups respectively.

- The specimen with coated bamboo reinforcement and steel stirrups performed the best where the observed ultimate load was 3.29 times that of plain concrete beam.

\section{REFERENCES}

1. Kumar, G. and D.K. Ashish, Review on feasibility of bamboo in modern construction. Jouranl of Civil Engineering, 2015. 2: p. 66-70.

2. Liese, W. and M. Köhl, Bamboo: the plant and its uses. 2015: Springer.

3. Espiloy, Z.B. Physico-mechanical properties and anatomical relationships of some Philippine bamboos. in International Bamboo Workshop. China. p. 1985.

4. Fang, H.-Y. and K. Ghavami, Low-cost and Energy Saving Construction Materials. 1984: Envo Publishing Company.

5. Huang, F. and W.J.J.o.M.S. Guo, Structural and mechanical properties of the spines from Echinocactus grusonii cactus. 2013. 48(16): p. 5420-5428.

6. Li, H. and S.J.J.o.M.R. Shen, The mechanical properties of bamboo and vascular bundles. 2011. 26(21): p. 2749-2756.

7. Paudel, S., Engineered bamboo as a building material, in Modern Bamboo Structures. 2008, CRC Press. p. 45-52.

8. Rao, K.M.M. and K.M.J.C.s. Rao, Extraction and tensile properties of natural fibers: Vakka, date and bamboo. 2007. 77(3): p. 288-295.

9. Soeprayitno, T., L. Tobing, and E.A. Widjaja. Why the sundanese of West Java Prefer Slope-inhabiting Gigantochloa pseudoarundinacea to those growing in the valley. in International Workshop on Bamboo. 1988. Cochin, India.

10. Tan, T., et al., Mechanical properties of functionally graded hierarchical bamboo structures. 2011. 7(10): p. 3796-3803.

11. Widjaja, E.A. and Z. Risyad. Anatomical properties of some bamboo utilized in Indonesia. in Recent Research on Bamboos. Proceedings of the International Bamboo Workshop. 1985.

12. Amada, S. and S. Untao, Fracture properties of bamboo. Composites Part B: Engineering, 2001. 32: p. 451-459.

13. Ghavami, K., Ultimate load behaviour of bambooreinforced lightweight concrete beams. Cement and Concrete Composites, 1995. 17(4): p. 281-288.

14. Liliefna, L.D., et al., Development of low-tech laminated bamboo esterilla sheet made of thin-wall bamboo culm. Construction and Building Materials, 2020. 242.

15. Fang, C.-H., et al., An overview on bamboo culm flattening. Construction and Building Materials, 2018. 171: p. 65-74.

16. Liu, X., et al., Nomenclature for engineered bamboo. BioResources, 2016.

17. Sharma, B. and A. van der Vegte, Engineered bamboo for structural applications, in Nonconventional and Vernacular Construction Materials. 2020, Elsevier. p. 597-623.

18. Glenn, H.E., Bamboo Reinforcement in Portland Cement Concrete, in Clemson University. Engineering Experiment Station. Bulletin, no. 4. 1950: Clemson College, Clemson, South Carolina.

19. Kankam J.A., Perry S.H., and M. Ben - George, Research on bamboo reinforced concrete one-way slabs subjected to line loading. International Journal for Development Technology, 1986. 4: p. p1-9.

20. J. K. Kankam, M.B.-G. and S.H. Perry, Bamboo-Reinforced Concrete Beams Subjected to Third-Point Loading. ACI Structural Journal, 1988. 85(1). 
Muhammad Fahim et al., International Journal of Advanced Trends in Computer Science and Engineering, 10(1), January - February 2021,382 - 388

21. Mali, P.R. and D. Datta, Experimental evaluation of bamboo reinforced concrete beams. Journal of Building Engineering, 2020. 28.

22. Terai, M. and K. Minami, Fracture behavior and mechanical properties of bamboo reinforced concrete members. Procedia Engineering, 2011. 10: p. 2967-2972.

23. Kankam, C.K. and B. Odum-Ewuakye, Flexural behaviour of babadua reinforced one-way slabs subjected to thirdpoint loading. Construction and building materials, 2001. 15(1): p. 27-33.

24. Naseer, A., Performance Behavior of Confined Brick Masonry Buildings under Seismic Demand, in Civil Engineering Department. 2009, University of Engineering and Technology: Peshawar, Pakistan.

25. Ali, Q., et al., Seismic Performance of Stone Masonry Buildings Used in the Himalayan Belt. Earthquake Spectra, 2013. 29. 